The identity of the label found in the eggs, its way of entry during oogenesis and its fate during further embryonic development are now being investigated.

W. J. Labordus-van Breukelen

C. J. H. VAN DEN BROEK

Department of Histology,

Faculty of Medicine,

University of Utrecht.

${ }^{1}$ Bieber, S., Spence, J. A., and Hitchings, G. H., Exp. Cell Res., 16, 202 (1959).

${ }^{2}$ Collier, J. R., and McCann-Collier, M., Exp. Cell Res., 27, 553 (1962).

${ }^{3}$ Durand, M., Bull. Biol. Fr. Belg., 95, 28 (1961).

- Hoff-Jörgensen, E., and Zeuthen, E., Nature, 169, 245 (1952).

'Agrell, I., and Persson, H., Nature, 178, 1398 (1956).

${ }^{6}$ Baltus, E., and Brachet, J., Biochim. Biophys. Acta, 61, 157 (1962).

${ }^{7}$ Chen, P. S., Exp. Cell Res., 21, 523 (1960).

\section{Measurement of the in vivo Degradation of Carbon-14-labelled Thymidine and Its Halogenated Analogues in Man by Continuous Monitoring of Expired Carbon-14-Carbon Dioxide}

THE rapid phosphorolytic cleavage of 5-bromodeoxyuridine (BUdR) and 5-iododeoxyuridine (IUdR) in vivo ${ }^{1,2}$ greatly limits the clinical usefulness of these thymidine analogues as antineoplastic agents ${ }^{3}$, radiosensitizers ${ }^{4}$, systemic antiviral compounds ${ }^{5}$, or detectors of malignant tissue $^{2}$. Investigations in man with halogen-labelled analogues have indicated that a greater amount of BUdR is probably retained by the body than is IUdR under nonloading conditions ${ }^{2}$. We have devised a rapid and convenient method, which permits one to make a direct comparison of the rate and extent of degradation of thymidine and its analoguos in the same subject, and to examine the effect of loading doses, depot administration ${ }^{6}$, and the influence of 5-fluorodeoxyuridine ${ }^{6}$, or agents designed to reduce nucleoside phosphorolysis ${ }^{7}$ on the degradation of the analogues.

As a consequence of thymine or uracil catabolism, carbon 2 of the pyrimidine rings is oxidized to carbon dioxide ${ }^{8}$. The rate and extent of degradation of $2 .{ }^{14} \mathrm{C}$ thymidine (TdR), $2-{ }^{14} \mathrm{C}-\mathrm{BUdR}$, and ${ }^{2-{ }^{14} \mathrm{C}-\mathrm{IU} \mathrm{dR} \text { have }}$ been compared in 11 adult patients after the intravenous administration of $10-\mu \mathrm{c}$. doses of each compound, with specific activities of 30,20 , and $11 \mathrm{mc} . / \mathrm{mM}$, respectively, utilizing an apparatus (General Measurements Corp., Garnerville, New York) which continuously monitors and records content of carbon dioxide and activity of earbon-14 in the expired breath. The injected materials and carbon dioxide and oxygen gas mixtures containing varying amounts of ${ }^{14} \mathrm{CO}_{2}$ were calibrated against standard ${ }^{14} \mathrm{C}$. carbonate sources obtained from the National Bureau of Standards.

Measurements were made for a period of $60-90$ min after injection of the labelled compound, and occasionally at later times. The digital output data from the detectors were analysed manually and were also programmed for computer analysis. During the first hour after injection, the carbon-14 expired in the breath, expressed as per cent of administered dose, was calculated from planimetric measurement of the area under the carbon-14 output curve or could be derived by computation from the digital data. The curve of decline in ${ }^{14} \mathrm{CO}_{2} /{ }^{12} \mathrm{CO}_{2}$ specific activity with time could be resolved into two exponentials, the slower of which had a mean half time of $84 \mathrm{~min}$ for TdR and about $60 \mathrm{~min}$ for BUdR and IUdR. From this value and the carbon-14 content of the breath at $60 \mathrm{~min}$, further extrapolation of the carbon-14 curve to zero values could be derived mathematically or graphically. The cumulative carbon-14 output after $1 \mathrm{~h}$ was added to the $1 \mathrm{~h}$ value to obtain the total carbon-14 expired. The mean percentage carbon-14 recoveries in the breath in the 11 subjects during the first hour after injection were $39 \pm 2,36 \pm 2$, and $43 \pm 2(S . E$.$) , for TdR, BUdR, and$
IUdR, respectively. The total mean carbon-14 recoveries, usually complete within $8 \mathrm{~h}$, were calculated to be $89 \pm 4,63 \pm 3$, and $90 \pm 3(S . E$.$) , respectively. In every$ patient the total recovery of carbon-14 after injection of carbon-14-BUdR was lower than that after TdR or IUdR administration. The urinary excretion of carbon-14, measured at the end of the experiment by liquid scintillation spectrometry, was low after injection of each of the labelled compounds, averaging about 2 per cent of the administered dose, with a range of $0 \cdot 1-5 \cdot 3$ per cent. The calculated mean net bodily retention of TdR, BUdR, and IUdR under these non-loading conditions was, therefore, about 9,35 , and 8 per cent, respectively. The radiation dose to the bone marrow and gonads incurred in any subject by performing the studies with these three carbon-14-labelled compounds has been estimated not to exceed $600 \mathrm{mr}$. /year at a concentration of $0.0006 \mu \mathrm{c} . / \mathrm{g}$ (maximal) assuming that, of the carbon-14 retained, 50 per cent will be distributed into the deoxyribonucleic acid (DNA) of the gastrointestinal tract, 20 per cent to bone marrow and gonads, and 30 per cent to the skin, and assuming a bone marrow and gonad weight of $1,500 \mathrm{~g}$ and permanent residence of the carbon-14 in DNA. (The total retained carbon-14 activity is less than $1 / 50$ th of the maximum permissible body burden ${ }^{9}$.)

These results have important implications for the systemic use of the halogenated thymidine analogues as anti-virus agents or as radio sensitizers. While these investigations do not provide evidence that all the retained carbon-14 is incorporated into DNA, there is ample evidence that the halogenated analogues have the capacity to replace thymidine during DNA synthesis ${ }^{6,10}$. Each of the analogues has radiosensitizing ${ }^{11}$ and antiviral $^{12}$ properties. The fact that BUdR is retained in 4-fold greater amount than is IUdR, therefore, suggests that greater clinical emphasis should be given to the former as a potentially useful chemotherapeutic agent.

This work was supported by U.S. Public Health Service grants $C A 06135-03 C Y$ and $C 5838$.

\section{JOSEPH P. KRISS}

Richard K. ShaW ROBERT LOEvinger NikKI EDMUNDS

Departments of Medicine and Radiology,

Stanford University School of Medicine,

Palo A.lto, California.

${ }^{1}$ Prusoff, W. H., Jaffe, J. J., and Gunther, H., Biochem. Pharmacol., 3, 110 (1960).

${ }^{2}$ Kriss, J. P., Maruyama, Y., Tung, L. A., Bond, S. B., and Révész, L., Cancer Res., 23, 260 (1963).

${ }^{3}$ Calabresi, P., Cardoso, S. S., Finch, S. C., Kligerman, M. M., von Essen, C. F., Chu, M. Y., and Welch, A. D., Cancer Res., 21, 550 (1961).

- Richardson, G. S., Hall, T. C., Green, T. H., and Ulfelder, H., Ann. N.Y. Acad. Sci., 97, 841 (1962)

' Calabresi, P., McCollum, R. W., and Welch, A. D., Nature, 197, 767 (1963).

${ }^{6}$ Clifton, K. H., Szybalski, W. Heidelberger, C. Gollin, F. F., Ansfield F. J., and Vermund, H., C̈ancer Res., 23, 1715 (1963).

' Kriss, J. P., and Bond, S. B., Biochemical Pharmacology, 13, 365 (1964).

${ }^{8}$ Schulman, M. P., Metabolic Pathways, edit. by Greenberg, D. M., 2, 439 (Academic Press, New York and London, 1961)

${ }^{9}$ Intern. Comm. Radiological Protection Rep. Committee II on Permissible Dose for Internal Radiation (1959) (Pergamon Press, London, 1960). ${ }^{10}$ Kriss, J. P., and Révész, L., Cancer Res., 22, 254 (1962).

11 Djordjevic, D., and Szybalski, W., J. Exp. Med., 112, 509 (1960).

12 Kaufman, H. E., Proc. Soc. Exp. Biol. Med., 109, 251 (1962).

\section{Relative Radiosensitivities of the Maternal Reproductive Tract and the Fertilized Ovum}

THE loss of pregnancy which occurs when an animal is subjected to large doses of irradiation has generally been ascribed to the radiosensitivity of the ova. However, an indication that the reproductive tract of the mother may be injured has been provided by Chang and Hunt ${ }^{1}$, who showed that pseudopregnant rabbits subjected to $400 \mathrm{r}$. had an increased incidence of embryonic mortality when ova which had not been irradiated were transferred 